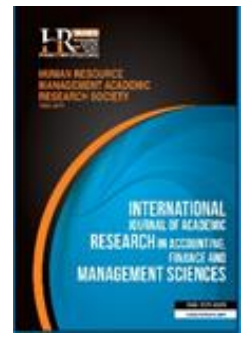

International Journal of Academic Research in Accounting, Finance and Management Sciences

Vol. 8, No.3, July 2018, pp. 1-16

E-ISSN: 2225-8329, P-ISSN: 2308-0337

(C) 2018 HRMARS

www.hrmars.com

To cite this article: Ugwu, J.I., Udeh, S.N. (2018). Influence of Foreign Direct Investment on Exchange Rate and Domestic Investment in Pre- and Post- IFRS Adoption Periods of Selected Sub-Saharan African Countries (19992015), International Journal of Academic Research in Accounting, Finance and Management Sciences 8 (3): 1-16.

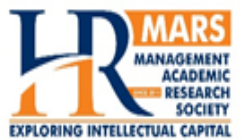

http://dx.doi.org/10.6007/IJARAFMS/v8-i3/4447 (DOI: 10.6007/IJARAFMS/v8-i3/4447)

\title{
Influence of Foreign Direct Investment on Exchange Rate and Domestic Investment in Pre- and Post- IFRS Adoption Periods of Selected Sub- Saharan African Countries (1999-2015)
}

\author{
James Ike UGWU1 ${ }^{1}$, Sergius Nwannebuike UDEH ${ }^{2}$ \\ 1,2Department of Accounting and Finance, Godfrey Okoye University, Enugu, Nigeria, \\ ${ }^{1}$ E-mail: Ugwujamesike@Gmail.com, ${ }^{2}$ E-mail: Sergius.Udeh@yahoo.com
}

\begin{abstract}
The study examined the influence of Foreign Direct Investment (FDI) on Exchange Rate (EI) and Domestic Investment (DI) in pre- and post-IFRS adoption periods of selected Sub Saharan African countries (Nigeria, Ghana and South Africa). Ex-post facto research design was adopted for the study. Secondary data were collected and analyzed using dummy Variable Regression technique. Findings revealed negative but insignificant influence of FDI on exchange rates of Nigeria and Ghana but South Africa was positive. FDI was also found to have had positive but insignificant effect on DI of Nigeria, Ghana and South Africa. However, there were no significant differences in the influence of FDI on the variables in pre-and post-IFRS adoption periods. The research recommends, amongst others, that government of these countries should ensure FDI inflows in areas where they do not have existing industries to avoid crowding influence of FDI. This could be in areas like value chain agro-allied industries. The study concludes that adoption of IFRS alone is not sufficient to attract significant FDI inflow to a nation.

Key words

Foreign Direct Investment, exchange rate, domestic Investment, International Financial Reporting Standards, Sub Saharan African Countries

\begin{tabular}{|c|c|c|}
\hline Received: & 18 Iun 2018 & (C) The Authors 2018 \\
\hline Revised: & $20 \mathrm{Jul} 2018$ & Published by Human Resource Management Academic Research Society (www.hrmars.com) \\
\hline $\begin{array}{r}\text { Accepted: } \\
\text { Published Online: }\end{array}$ & $\begin{array}{l}30 \text { Jul } 2018 \\
09 \text { Aug } 2018\end{array}$ & $\begin{array}{l}\text { This article is published under the Creative Commons Attribution (CC BY } 4.0 \text { ) license. Anyone may } \\
\text { reproduce, distribute, translate and create derivative works of this article (for both commercial and non- } \\
\text { commercial purposes), subject to full attribution to the original publication and authors. The full terms of } \\
\text { this license may be seen at: http://creativecommons.org/licences/by/4.0/legalcode }\end{array}$ \\
\hline
\end{tabular}
\end{abstract}

\section{Introduction}

There is a wide spread belief by policy makers, especially among developing nations, that Foreign Direct Investments (FDI) promote and enhance productivity of host nation, thus increasing economic growth and development. Most often, in a bid to achieve and sustain economic growth and development, developing nations may be constrained by shortage of fund. This might be due to inadequate domestic savings. In Sub-Saharan African countries, domestic private savings have proven to be insufficient in giving the sub-region the desired level of economic growth (Kanu, 2015). To cover the gap between savings and their desired rate of growth, external sources of fund are usually sourced. These foreign capitals, which are expected to be channeled towards productive activities, are usually in the form of foreign direct investments, foreign portfolio investments, foreign aids and grants, economic migrant remittances and external debts. World Bank (2002) in Tshepo (2014) asserts that FDI promotes development of the host country through productive growth, exports, transfer of technology and creating employment for the working class citizens of the host country. The investors are likely to come in with their technology, managerial skills and employ the host country's citizens who are expected to understudy them. Such 
symbiotic relationship might result in transfer of technology and enhancement of managerial skills of the citizens involved (Ugwu, 2017). The rate at which the above proposition takes place depends on the host nation's possession of absorptive capacities to enable them benefit from such investment in the long run (Alfaro et al., 2006).

In view of the presumed benefits in Sub-Saharan Africa, there were moves by the various governments towards attraction of FDI into their countries. To that effect, some structural adjustments and legislative enactments such as the Export Processing Free Trade Zone Scheme (EPFTZS) established in 1991 with the enabling act coming into effect in 1992 have been initiated by Nigeria. The scheme which aims at acceleration of exports through increased production provided a lot of incentives to investors (Nwaimo, 2009). In 1995, the Nigerian Investment Promotion Act No 16 of 1995 came into effect, and together with others, repealed series of hitherto laws that imposed strict control on foreign investment. Notable among them was the Industrial Development Coordination Committee Decree No. 36 of 1988 and the Nigerian Enterprise Promotion Decree of 1972. The Investment Promotion Act of 1995 established the legal foundation for a very liberal and open investment framework. It is a cross-sectoral legislation which aims at encouraging inflow of foreign investments in all sectors of the economy. It allows foreigners to invest and participate in the operation of any Nigerian enterprise without any restriction. It allows $100 \%$ foreign ownership of firms, except in the oil and gas sector, where it restricts investments to joint ventures or production-sharing agreements. It allows repatriation of profits/dividends to home country in any convertible currency. The provisions of Foreign Exchange Monitoring and Miscellaneous Provision Act (FEMMP) of 1995 and some provisions of Companies and Allied Matters Act of 2004, as amended, could be adjudged as complementary to the Investment Promotion Act.

Furthermore, Ghana passed the Investment Act Code of 1985 (PNDCL 116), now replaced by Ghana Investment Promotion Centre Act, of 1994 (Act 478) and amended in 2013 (Act 865) with functions that included but not limited to formulating investment promotion policies and plans as well as providing promotional incentives and marketing strategies to attract foreign and local investments in advanced technology industries and skill-intensive services which enjoy good export market prospects.

Ghana had structural adjustment programme (SAP) launched in 1983 and Nigeria implemented hers in 1986, both aimed at implementing and complying with International Monetary Fund (IMF)/World Bank polices of liberalizing the economies of the nations concerned. One of the major pivots of SAP was the attraction of foreign investment (Abu and Achegbulu, 2011). In South Africa, investment promotions were done by Department of Trade and Industry. This has five strategic objectives all aimed at investment promotion with emphasis on policies, legislation and regulations, financial support and investment incentives, information and advisory support as well as value-added partnerships.

Some of those attracted companies have been in operation over many years. The concern is to ascertain the effects of the activities of these companies on the economy of their host country as there has been report that FDI may not contribute significantly to the economic growth of the host country. For instance, the recent revelation that MTN-Nigeria illegally transferred out $\$ 12$ billion from Nigeria indicates that some of the FDI led companies could be involved in activities that result in capital flight. The 11month-long investigation report showed that the company had been running around Nigerian revenue authorities using a complex but noxious tax avoidance scheme called Transfer Pricing between 2006 to 2016 (Premium Times, September 22, 2016). M Premium Times established that MTN Nigeria had been making payments to two overseas companies - MTN Dubai and MTN International in Mauritius - both located in tax havens. Through that, the amount of tax payable to Nigeria was reduced. This and other similar activities of the FDI-led companies might have accounted for little or insignificant growth in the economy of host countries.

Measurements of the performance of a nation's economy could be done through measurement of economic growth and economic development. Economic growth is the rate of change of real income or real output, which is usually ascertained by Gross Domestic Product (GDP) which measures the total output of an economy (Begg et al., 2008). Other economic growth indicators include exchange rate and domestic investments. Domestic Investment (DI) could be seen as those firms whose capital requirements and control are from within a nation's border. Its output contributes to the national GDP. However, there has been conflicting opinions on the effect of FDI inflows on domestic investment (Amighini et al., 2015). One 
of the major debates is whether FDI 'crowds in' or 'crowds out' DI (Ndikumana and Verick, 2007 and Ullah et al., 2014). Where FDI leads to a new or increase in the amount of DI which would not have been possible in absence of FDI, it is said to have a 'crowding in' effect but where it leads to loss of competitiveness and other developments adverse to domestic investment, it could be viewed as a 'crowding out' effect.

In international business, the issue of exchange rate is usually at fore front in other to transform foreign currency or statement of account to the understanding of the parent companies or for purposes of consolidation. Exchange rate refers to the price of a country's currency in terms of another foreign currency (Ezejelue, 2001). The value of a nation's currency is a reflection of the strength of her economy as it is associated with demand of her goods and services which indicates the level of her productive and service capacity. Furthermore, adoption of International Financial Reporting Standards (IFRS), which amongst other things, aims at harmonization of accounting reports from various countries is also expected to increase FDI inflow into the adopting nations. The information provided while using IFRS are usually clear thus reducing business risk. Gordorn, Loeb and Zhu (2012) contend that adoption of IFRS provides quality financial information, thus encouraging FDI.

The contribution of these FDI-led companies to the economic growth of the nations has been the subject of discourse as there is no consensus yet among scholars on their effect on economic growth indices like exchange rate and domestic investment. This is due to differences in the findings by various scholars at different studies. For instance, there have been varied results on the effect of FDI on DI; some revealed bi-directional causal relationship as in the works of Ndikumana and Verick (2007), and Ullah, (2014). Cristina (2014) discovered that FDI crowd out DI but Razin (2004) and Agosin and Mayer (2010) found that FDI crowd in DI in Asia and Africa but crowd out in Latin America. However, Prasanna (2010a) in his study found no evidence of crowding in or crowding out. Froot and Stein (19991) found that FDI leads to depreciation of the currency while Osigwe and Uzonwanne (2015) discovered evidence of unidirectional causality running from exchange rate to FDI. These inconsistencies in their findings make the effects of FDI on some of these economic variables subject of debate, thus calling for further studies in this field; hence this study.

\subsection{Objectives of the Study}

The main purpose of the study is to ascertain the influence of FDI on exchange rate and domestic investments in post IFRS adoption of selected Sub-Saharan African countries. The study specifically addressed the following objectives:

1. To ascertain the influence of FDI on exchange rate in pre- and post-IFRS adoption periods in Nigeria, Ghana and South Africa.

2. To evaluate the influence of FDI on domestic investment (gross fixed capital formation) in preand post-IFRS adoption periods in Nigeria, Ghana and South Africa.

\subsection{Research Hypotheses}

In pursuance of the above objectives, the following hypotheses were formulated:

1. The influence of FDI on exchange rate in the post- IFRS adoption period is not significantly different from the pre- IFRS adoption periods in Nigeria, Ghana and South Africa.

2. The influence of FDI on domestic investment in the post- IFRS adoption period is not significantly different from the pre-IFRS adoption periods in Nigeria, Ghana and South Africa.

\subsection{Scope}

The study covered the influence of FDI on exchange rate and domestic investment of Nigeria, Ghana and South Africa for the period 1999-2015. This was the period when all the countries of study were in uninterrupted democratic rule. This study delimited FDI to FDI inflows only. In 2012, 2007 and 2005 Nigeria, Ghana and South Africa adopted IFRS respectively. The pre-IFRS adoption period spanned from 1999 and ended the year before its adoption in each of the countries of study while post adoption period started from the year of adoption to 2015. 


\section{Literature review}

\subsubsection{Concept of FDI}

A direct investment enterprise is an incorporated or unincorporated enterprise in which a single foreign investor either owns 10 per cent or more of the ordinary shares or voting power of an enterprise (unless it can be proven that the 10 per cent ownership does not allow the investor an effective voice in the management) or owns less than 10 per cent of the ordinary shares or voting power of an enterprise, yet maintains an effective voice in management (Organisation for Economic Co-operation and Development; OECD, 1996). Abbas et al. (2011) are of the opinion that FDI refers to net inflows of investment in an economy of a country comprising the sum of equity capital, reinvestment of earnings, long term and short term capital. Omoniyi and Omobitan (2011) consider FDI as expansion of international activities of Multinational Corporations. Furthermore, Todaro and Smith in Otto and Ukpere (2014) define FDI as oversea investment by private multinational corporations. In the same vein, Graham (1995) refers to increase in book value of all investment held in one country by investors from another country and managed or controlled by the investor as FDI. Ugwu (2017) defines FDI as cross-border investment by individuals, group, company or government in another country with intent to get control of the firm and make profit.

Meigs et al. (1999) note that global environmental forces contribute in shaping globalization, asserting that companies considering international operations as a means of fulfilling strategic objectives need to understand how international environmental forces affect the accounting information measured, reported and created. They considered four categories of environmental forces namely; political and legal system, economic system, culture and technology and infrastructure. However, the adoption of International Financial Reporting Standards (IFRS) has helped in harmonization of accounting reports through the IFRSs provisions (Epstein and Jermakowic, 2009, Alexander et al., 2009 and Collings, 2012).

Agosin and Mayer (2000) opine that FDI is prized by developing countries for the bundle of assets that Multinational Enterprises (NNEs) deploy with their investment most of which are intangible (like technology, management, skills channels for marketing products internationally, product design, quality characteristics and brand names) and scarce in developing countries. These assets could help in improvement in quality and quantity of goods produced as well as market share of the enterprise concerned. From the above, FDI simply means cross boarder investment by citizens of one country in another country.

\subsubsection{FDI and Exchange Rate}

A currency exchange rate is the amount it costs to purchase one unit of currency with another currency (Meigs et al., 1999). It is also regarded as the value of one country's currency in terms of another, thus having two components: domestic currency and foreign currency and can be quoted directly or indirectly (Osigwe and Uzonwanne, 2015). In indirect quotation, the price of a unit of domestic currency is expressed in terms of foreign currency while in direct quotation, exchange rates are determined in foreign exchange market where currencies are traded. Changes in flexible exchange rate, is due to changes in demand and supply of the currencies involved. The change in demand and supply could arise as a result of increase in domestic price of exports, rise in the foreign price of imports, general changes in price levels, major capital movement and structural changes (Lipsey and Chrystal, 2011). They went further to assert that a significant movement of investment funds has the effect of appreciating the currency of capitalimporting country and depreciating the currency of the capital-exporting country. Lily et al. (2014) added that FDI can also influence the appreciation or depreciation of the local exchange through the increased demand for home currency. It is worthy of note that in International Financial Reporting Standards (IFRS), International Accounting Standard (IAS) 21 states requirement for individual entity's foreign currency transactions (Alexander et al., 2009). IFRS aims at harmonization of accounting practices world-wide and by so doing creates uniform treatment of transactions through its various sections and provisions. 


\subsubsection{FDI and Domestic Investment (DI) or Gross Fixed Capital Formation (GFCF)}

Arndt et al. (2007) in an attempt to establish theoretical linkages between FDI and DI investigated the effect changes in the activities of multinational firms have on domestic firms via changes in output price and linkages between firms in different industries. To capture the relationship, they used production function that captures the complementarities between domestic and foreign capital. It revealed that linkage effect arose through demand and supply linkages between multinationals and local firms. The linkage can generate positive spillovers between multinationals and domestic production which can overturn potential negative product or factor market effects. The above findings are in agreement with the view of Prasanna (2010) that the inherent characteristics of FDI influencing investment in the host country is both direct and indirect; directly through their own investment activities and indirectly through affecting investment by the host country's firms.

However, Agosin and Mayer (2000) while contributing to the effect of FDI on DI and total investment contended that the effect on investment may vary from country to country, depending on domestic policy, the kind of FDI the country received and strength of domestic enterprises. They argued that FDI inflow into developing countries that introduce goods and services that are new in the economy be it for export or domestic market are more likely to have positive effect on capital formation than FDI in areas where there already exist domestic producers. While in the former, the foreign producer freely produces and contributes to the economy in areas where the local investors lack the capacity, in the latter, they may displace the local investors through superior technology, skill, management and economies of the scale which are usually to their advantage. Furthermore, Razin (2004) expressed the gains associated with FDI thus: firstly, there is conventional gain arising from new flow of capital to the economy and secondly, from intrinsic gain associated with superior micro management.

\subsection{Theoretical Review: The Elective Theory}

Dunning (1988) developed the elective theory which consists of three different theories that tend to explain FDI. It attempts to explain why a firm would like to produce in a foreign location instead of exporting or entering into a licensing arrangement with a local firm. These theories include: Ownership advantage, Location and Internalization (OLI model). Ownership advantage refers to factors that enable firms to overcome handicaps in an alien environment like language and culture, access to inputs, legal system and tax regime. It refers to the intangible assets which belong solely to a firm and may be transferred within Multinational Corporations (MNCs) at low costs in order to increase revenue or to reduce costs (Denisia, 2010). Ownership advantage may be in the form of superior technology, managerial and marketing skills which give the firm competitive edge over other local firms. Location in this respect refers to host nation where the MNCs might decide to locate their foreign affiliate. Rather than exporting to the area, it becomes more profitable establishing a new firm there due certain factors like cheap labour, availability of raw materials and large market. Denisia (2010) further argues that cross border production and internalization increases firm preference to produce in the host country rather than giving franchise or offer rights under licenses. Aveh et al. (2013) note that OLI is firm specific which depends on economic, political and social atmosphere of the host country in which the firm operates.

The study was anchored on this theory because the theory vividly exposes conditions favourable to FDI investment.

\subsection{Empirical Review}

\subsubsection{Exchange Rate}

There are few studies on the effect of FDI on exchange rate of nations. Lily et al. (2014) empirically analyzed the exchange rate movements and FDI relationships using annual data from some Asian economies-Malaysia, Philippines, Thailand and Singapore for the period 1971-2011. OLS was used for data analysis. Unit root tests were performed employing ADF, Phillips Perron (PP) as well as Dickey-FullerGeneral Least Square (DF-GLS). Also, used was Autoregressive Distributed Lag (ARDL) bound testing approach for cointegration to check the long-run movement of the variables. Result showed in cases of Singapore and Philippines long-run bi-directional causality between exchange rate and FDI whereas long- 
run unidirectional causality running from exchange rate to FDI exists in Malaysia. In any case, short-run unidirectional causality running from exchange rate to FDI was found in Singapore.

Osigwe and Uzonwanne (2015) scrutinized the granger causality of foreign reserve, exchange rate and FDI in Nigeria. ADF and PP were adopted to test for stationarity of the variables. Causality among the variables was traced using Johansen cointegration technique and the Granger Causality test (GCT). Result of the analysis suggested long run relationship among foreign reserve, FDI and exchange rate. GCT indicated a unidirectional causality runs consistently from exchange rate to foreign reserve from lag one to three. From lag one to two, it also indicated unidirectional causality from FDI to foreign reserve. However, at lag three, it showed bidirectional Granger causality between foreign reserve and FDI. Furthermore, evidence of unidirectional causality running from exchange rate to FDI was discovered from lag one to three.

Froot and Stein (1991) descriptively examined the connection between exchange rate and FDI of USA that arose when global integrated capital markets were subjected to informational imperfections such that external financing became more expensive than internal financing. The associated changes in wealth translated into change in demand for domestic investment. A depreciation of domestic currency was associated with increase in FDI inflows. Similarly, Goldberg (n.d.) reviewed the exchange rate - FDI relationship in USA. The descriptive analysis led to conclusion that exchange rate volatility can contribute to the internationalization of production activity without depressing economic activity in the home market. He added that actual movement of exchange rate can also influence FDI through relative wage channels, relative wealth channels and imperfect capital market arguments. The results of various researches have not been uniform as could be seen from the works reviewed above. The non- uniformity calls for further studies in this field.

\subsubsection{Domestic Investment (Gross Fixed Capital Formation)}

Ndikumana and Verick (2007) analyzed the two way linkages between FDI and Domestic Investment (DI) in Sub-Sahara Africa; that is whether DI promotes FDI inflows and is in turn affected by FDI. Thirty eight Sub Saharan African countries were involved in the study covering the period 1970-2005. Data were analyzed using OLS. It revealed a bi-directional effect of FDI and DI. It showed that DI attracts FDI inflow into those nations while FDI crowd in DI in them as well. Ullah et al. (2014) studied the dynamic interaction among DI, FDI and economic growth in Pakistan for the period 1976-2010. Phillips Perron test, Johansen Cointegration and Tado-Yamamoto causality approach were used for analysis. Result showed long-run relationship between DI, FDI and economic growth. It also showed bidirectional causality between FDI and DI.

Cristina (2014) investigated the relationship between FDI and local investment using a sample of 10 countries from Central and Eastern European Countries (CEEC) over the period 1990-2010. DI was the dependent variable while FDI was the explanatory variable. General method of moments (GMM) was applied for the estimation. The result revealed that FDI crowd out DI.

Prasanna (2010) examined the direct and indirect impact of FDI on DI in India for the period 1991-92 to 2006-07. The dependent variable was DI while the independent variable was FDI. Multiple linear regression models were used for the analysis to ascertain the relationship between the FDI and the DI while Wald test was used to determine the long-term crowding in or out of FDI on DI. Data consistency was checked using ADF. The variables were stationary in their original form (no unit root problem). In the short run, FDI had positive effect on DI but in the long run, there was no evidence of crowding in or crowding out of DI. Razin (2004) explored the contribution of FDI to DI in capacity and vice versa. He used econometric approach for the estimation of the interaction between DI, FDI inflow, international loan and international portfolio investment. Sixty four countries were used in the study covering the period 1976-1997. OLS and Two Stage Least Square (TSLS) regressions were employed in the analysis. The result showed positive coefficient of domestic investment and is significant in both OLS and TSLS with long-run effect of OLS being smaller than that of TSLS.

Agosin and Mayer (2000) investigated whether FDI crowd in or crowd out DI using a version of the model with 'Adaptive expectation' with respect to growth rate which was estimated for a panel of 32 countries (12 in Africa, 8 in Asia and 12 in Latin America) over the period 1970-1996. The test was 
conducted in two versions: in one version, growth rate as the only explanatory variable for DI while in the second, a proxy for the gap between actual and full capacity was incorporated and estimated using Hodrick-Prescott filter for two sub periods of 1970-1985 and 1986-1996. The model was run for the three developing regions (Africa, Asia and Latin America). The result revealed that in Asia -but less so in Africathere has been strong crowding in of DI by FDI but in Latin America, strong crowding out effect was found.

Mahmood and Chaudhary (2012) carried a study on the relationship between FDI and DI in Pakistan for the period 1972-2010. The independent variables were FDI, Financial market development and GDP growth rate while DI was the dependent variable. OLS was employed for analysis of data while diagnostic tests were done using ADF, PP, Ng-Perron and Zivot-Andrews unit root tests. The study found all variables were stationary at first difference. There were long-run and short-run relationships among the variables. FDI had a positive crowding in effect on DI in Pakistan in the period under review. Also, GDP, financial market development had positive relationship with DI.

\subsubsection{IFRS}

Adeula et al. (2014) evaluated the impact of IFRS on FDI as it affects the Nigerian economy. Secondary data were collected from World Development indicators, while primary data were collected from managers and preparers of financial statements of companies that have adopted IFRS. Analysis was done using one sample t-test for primary data while correlation and regression were used for secondary data. Result showed that there is positive but insignificant relationship between FDI inflow and IFRS adoption and that the longer a country uses IFRS the higher the FDI. Sherman and de Klerk (2015) investigated IFRS adoption and foreign ownership level in 40 (IFRS adopted) listed South African listed companies for the period 2003-2007. Result revealed IFRS adoption did not have significant positive association with foreign ownership levels during the sample period.

Pricope (2017) evaluated the impact of IFRS adoption on FDI inflow of poor countries using Propensity Score Matching Method on samples of 38 poor countries, between 2008 and 2014. Probit Model was used to compute the propensity scores. The investigation indicated that IFRS had a positive impact on FDI flows in poor countries. Similarly, Akpomi and Nnadi (2017) evaluated the effect of IFRS on FDI of African countries using unbalanced panel data from 45 countries spanning from 1996-2011. Result of OLS analysis revealed that IFRS had positive effect on FDI inflows.

Efobi et al. (2014) investigated the effect of IFRS adoption on FDI and the role institutions play in the relationship using sample of 92 countries from developed and developing nations for the period 2002-2010. General Method of Moments estimate technique was used for the estimation. It was found that IFRS was not able to attract much FDI and that institutional development played a substitutive role in that regard. In the same vein, Jinadu et al. (2016) evaluated whether IFRS adoption has impacted significantly on FDI inflow into Nigeria. Questionnaire was used for data collection while data analysis was done with regression method. Result of the analysis revealed that IFRS adoption was positively and significantly related to FDI inflow in Nigeria.

Henock and Oktay (2012) examined the effect of IFRS on FDIs. They sort to ascertain whether the mandatory adoption of IFRS could lead to increased cross-border acquisitions in the adopting countries in European Union (EU). They standardized the number of acquisitions from overseas by the number of local acquisitions to obtain a measure of the probability of a cross-border acquisition. Logistic Regression was applied for the analysis of data. Results indicated that the average proportion of cross-border acquisition of listed companies in the adopting countries were significantly larger after adoption of IFRS. Similarly, Jayeoba et al. (2016) studied the consequences of adoption of IFRS on FDI of selected African countries (Egypt, Nigeria, Kenya, Morocco, Tunisia and South Africa) for the period spanning from 1980-2015. Descriptive analysis and inferential statistics (Granger Casualty Test, Hausman Test and Regression Analysis) were adopted for data analysis. The results suggested that adoption of IFRS had significant positive effect on FDI inflows.

\section{Methodology of research}

The study adopted Ex-Post-Facto research design. Secondary data were collected from United Nations Conference on Trade and Development (UNCTAD), World Investment Reports, (2016); United 
Nations Statistics, national accounts main aggregate data base (2015) and Index Mundi, (2015). The population of the study is Sub Saharan African Countries comprising 42 countries. Judgemental sampling technique was adopted for the study using the three countries with highest FDI inflow for the period under review, 1999-2015 with Nigeria having \$79472.1million, South Africa, \$70763.5 million and Ghana, \$25343.8 million (World Investment Report, 2016). The three countries started uninterrupted democracy in 1992, 1994 and 1999-(Ghana, South Africa and Nigeria respectively) and adopted IFRS in 2012, 2007 and 2005 for Nigeria, Ghana and South Africa respectively (Ugwu, 2017). Study of countries of similar characteristics will reduce the incidence of heterogenity that might lead to spurious results.

Data were analyzed using Dummy Variable Regression. This is more appropriate than Chow Regression because of the small sample size. While in Dummy Variable model, all observations are pooled in on regression, in chow Regression the observations are divided into two (pre and post) which in this work will introduce small sample bias (Gujarati et al., 2009).

Model I: The influence of FDI on exchange rate (EXR) of Nigeria, Ghana and South Africa The model used to estimate impact of EXR for Nigeria, Ghana and South Africa is shown below.

$$
E X R=f(F D I, I N F, T O P, \text { Dummy })
$$

Where: $\mathrm{EXR}=$ Exchange rate, $\mathrm{FDI}=$ Foreign direct investment, $\mathrm{INF}=\mathrm{Inflation}, \mathrm{TOP}=$ trade openness. N/B: Inflation and trade openness were introduced as control variables

The above model can be transformed for estimation as shown below

$$
\log \operatorname{exr}_{i t}=\lambda_{0 i}+\lambda_{1 i} D_{i t}+\lambda_{2 i} \log f d i_{i t}+\lambda_{3 i}\left(\text { Dummy }_{i t} * f d i_{i t}\right)+\lambda_{4 i} \inf _{i t}+\lambda_{5 i} \text { top }_{i t}+\mu_{i t}
$$

Where $(i=1,2,3)$ and hence represent Nigeria, Ghana and South Africa respectively and $t$ is from 1999-2015.

Model II: The influence of FDI on Gross Fixed Capital Formation (GFCF) that is DI of Nigeria, Ghana and South Africa

The model below was used to estimate effect of FDI on the GFCF for Nigeria, Ghana and South Africa

$$
G F C F=f(F D I, I N F, T O P, \text { Dummy })
$$

Where: GFCF = gross fixed capital formation and the other variables areas already defined.

The above model can be transformed as below for estimation

$$
\log g f c f_{i t}=\alpha_{0 i}+\alpha_{1 i} D_{i t}+\alpha_{2 i} \log f d i_{i t}+\alpha_{3 i}\left(\text { Dummy }_{i t} * f d i_{i t}\right)+\alpha_{4 i} \inf _{i t}+\alpha_{5 i} t_{o p}+\mu_{i t}
$$

Where: $(i=1,2,3)$ and hence represent Nigeria, Ghana and South Africa respectively and $t$ is from 1999-2015

\section{Data Presentation and Analysis}

\subsection{Data Presentation}

Data on the macro-economic variables collected for analysis for the three countries of study were presented in tables and graphs. They contain data of, FDI, DI, Exchange Rate, Inflation and Trade Openness. See appendix for tabular presentation of data.

Graphical presentation of FDI data are shown in figure 1.

From the figure1, it could be observed that Nigeria had a relative progressive increase in FDI inflow from 1999 to 2009. She had a sharp drop in 2010 but rose quickly to reach its peak for the period in 2011. Since the adoption of IFRS in 2012, there has been a steady decline. In contrast, Ghana had relatively smaller FDI inflow but had a progressive increase over the years with minor drop in 2010 and 2015. 


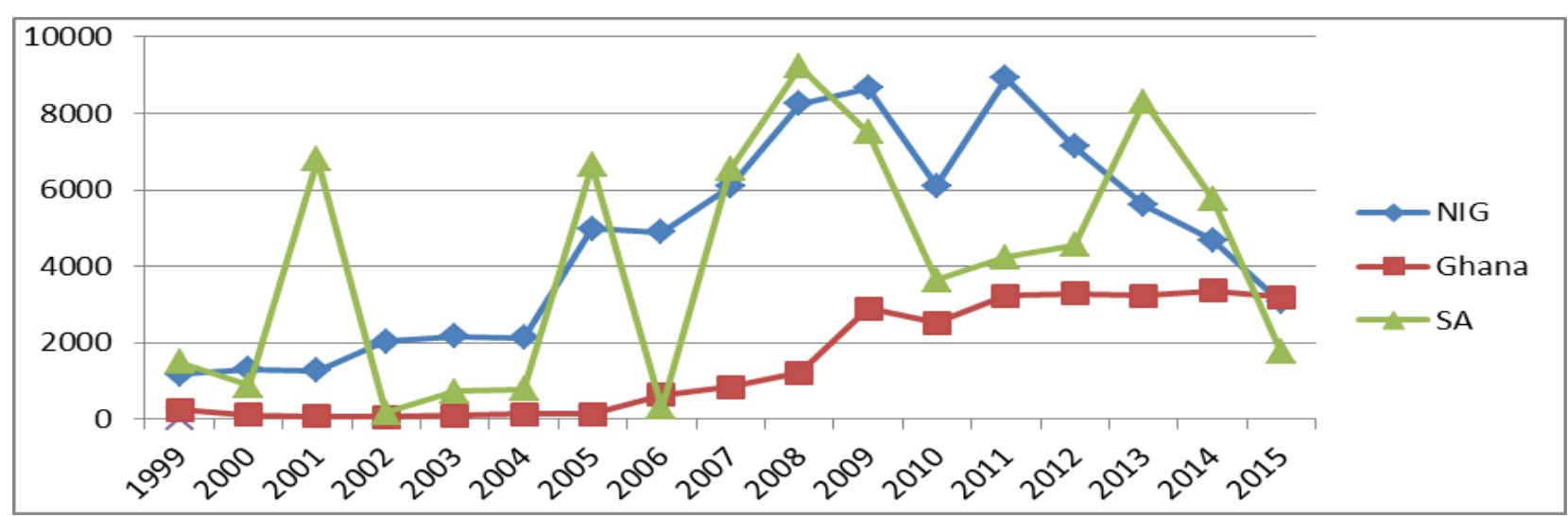

Figure 1. Graph showing trend in FDI inflows to Nigeria, Ghana and South Africa

Post-IFRS adoption period (2007-2015) had remained consistently higher than the pre adoption period. However, South Africa had highly unstable FDI inflow which has been characterized by sharp rise and crash as such is unpredictable in both pre- and post-IFRS adoption periods with post period (20052015) being consistently higher. Graphical presentation of exchange rate data is shown in figure 2.

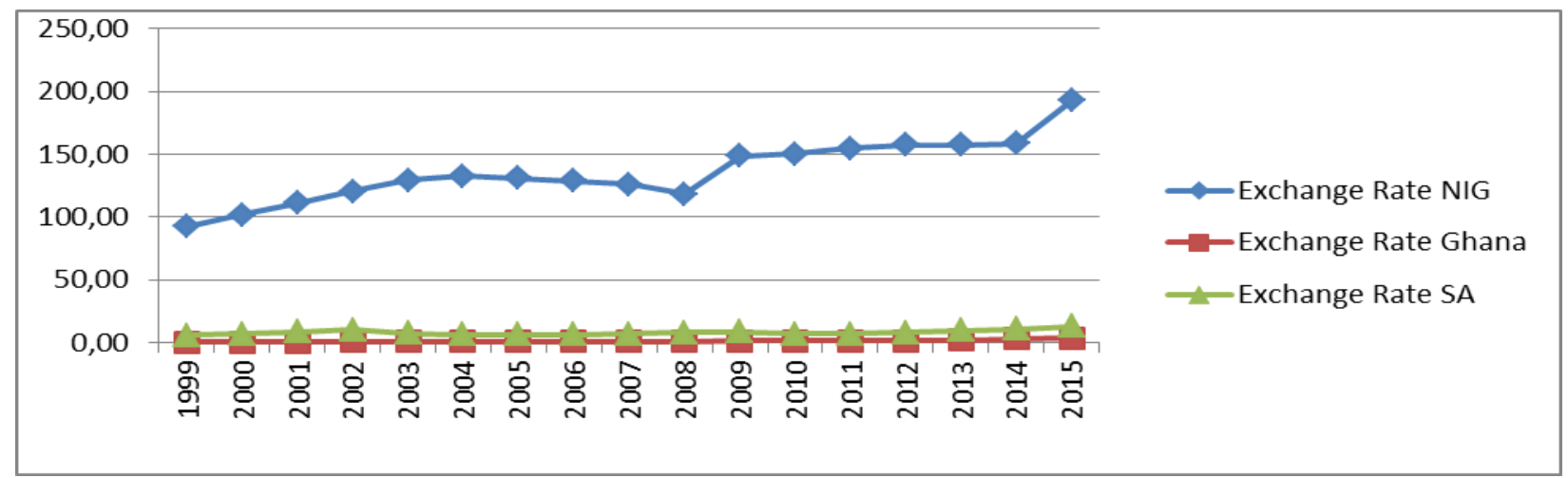

Figure 2. Graph showing trend of Exchange Rate of Nigeria, Ghana and South Africa currencies to US\$

Figure 2 shows a pictorial representation of the data on table in appendix. At a glance, one would notice high value of Nigeria's exchange rate, which implies that the rate of exchange of Naira to a dollar was higher, that is, more naira was needed to exchange for a dollar compared to Ghana and South Africa. Ghana and South Africa were crawling just above the x-axis.

Graphical presentations of DI data are shown in figure 3.

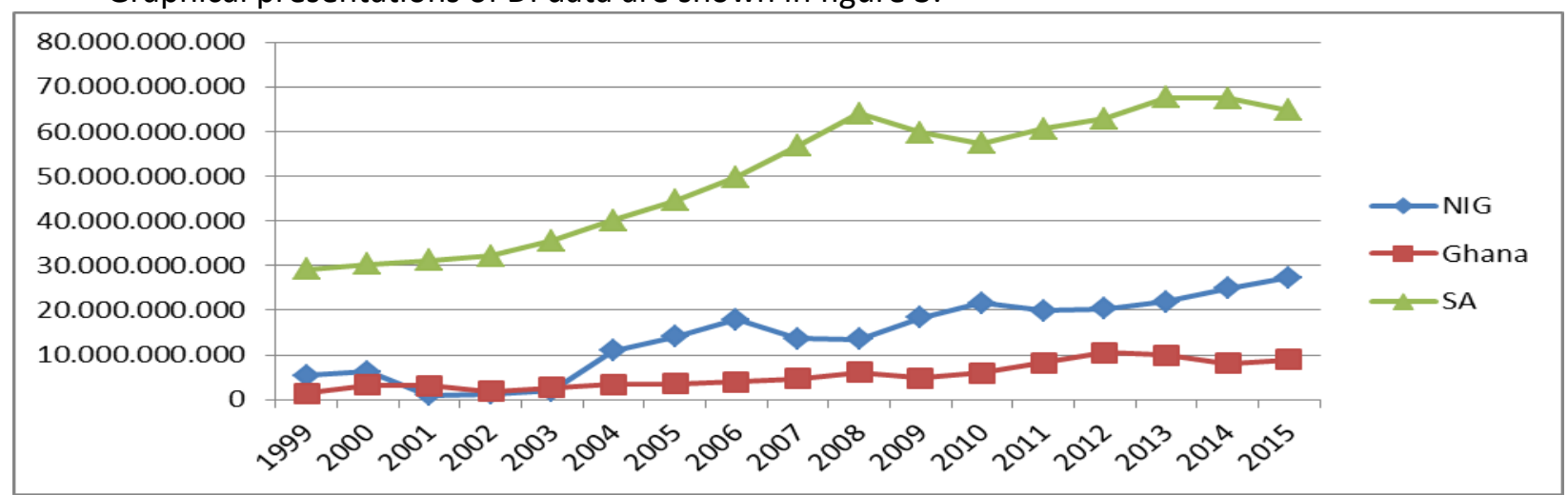

Figure 3. Graph showing trend of Domestic Investment of Nigeria, Ghana and South Africa in US\$

In the figure 3, South Africa's DI curve is conspicuously higher than that of Nigeria and Ghana reaching its peak in 2013. Nigeria's undulating curve trailed behind with her peak in 2015. Post IFRS 
adoption (from 2011-2015) showed steady improvement in her DI. Ghana had fluctuating DI curve in both pre- and post- IFRS era but below that of Nigeria.

\subsection{Data Analysis}

Inferential statistics (Dummy Variable Regression) were adopted for data analysis.

\subsubsection{Unit Root Test}

Non stationary time series data when used in regression produces spurious regression result (Gujarati, 2004), hence the need for check for stationality of the data.

Table 1. Unit root test on the variables

\begin{tabular}{lllllll}
\hline & \multicolumn{2}{c}{ Nigeria } & \multicolumn{2}{c}{ Ghana } & \multicolumn{2}{c}{ South Africa } \\
\hline Variable & ADF at Level & ADF 1st DIFF & ADF at Level & ADF 1st DIFF & ADF at Level & ADF 1st DIFF \\
Logfdi & -1.6392 & $-3.5179^{* *}$ & -0.8149 & $-4.1255^{* *}$ & -1.9091 & $-4.5463^{* * *}$ \\
& $(0.4362)$ & $(0.0227)$ & $(0.7853)$ & $(0.0161)$ & $(0.3196)$ & $(0.0044)$ \\
Logtop & -1.4685 & $-3.8509^{* *}$ & -2.5969 & $-3.7019^{* *}$ & -1.9269 & $-3.6638^{* *}$ \\
& $(0.5230)$ & $(0.0122)$ & $(0.1182)$ & $(0.0073)$ & $(0.3127)$ & $(0.0173)$ \\
Inf & -2.1439 & $-5.9945^{* * *}$ & -2.9580 & $-3.6185^{* *}$ & -2.8178 & $-4.0153^{* * *}$ \\
& $(0.2321)$ & $(0.0003)$ & $(0.0607)$ & $(0.00229)$ & $(0.0827)$ & $(0.0090)$ \\
Logexr & -2.3294 & $-6.1945^{* * *}$ & -1.3933 & $-3.4956^{* *}$ & -0.4823 & $-4.9211^{* *}$ \\
& $(0.1796)$ & $(0.0002)$ & $(0.5590)$ & $(0.0482)$ & $(0.8710)$ & $(0.0095)$ \\
Logdinv & -2.2474 & $-5.9945^{* * *}$ & -1.9944 & $-6.3670^{* * *}$ & -1.5737 & $-3.8798^{* *}$ \\
& $(0.6243)$ & $(0.0003)$ & $(0.2859)$ & $(0.0002)$ & $(0.4723)$ & $(0.0317)$ \\
\hline
\end{tabular}

**" and "***" Represent that the variable is integrated at $5 \%$ and $1 \%$ respectively.

Source: Researchers' Computation, 2018.

$P$ values are in parenthesis

Table 1 shows the Unit Root property of the variables. The ADF result indicates that all the variables in each of the countries were integrated at first difference as evidenced by their probability values which were greater than 0.05 at level form but less 0.05 at first difference. As a result, the null hypothesis of unit root is accepted for all the variables at their level form from the three countries. Each of the variables when differenced, appeared stationary at either 5 per cent or 1 per cent or both, thus the null hypothesis of unit root is rejected for all the variables at their first difference as seen in their probability figures which were significant $(<0.05)$.

\subsubsection{Cointegration Test}

Table 2. Unit root test on the error term

\begin{tabular}{lccc}
\hline & Nigeria & Ghana & South Africa \\
\hline Equations & ADF at level for error term & ADF at level for error term & ADF at level for error term \\
LOGDINV & $-3.06964^{* * *}$ & $-4.55531^{* * *}$ & $-3.3226^{* *}$ \\
EQUATION & $(0.0045)$ & $(0.0002)$ & $(0.0025)$ \\
LOGEXR & $-4.36281^{* * *}$ & $-4.3522^{* * *}$ & -0.1666 \\
EQUATION & $(0.0006)$ & $(0.0002)$ & $(0.6105)$ \\
\hline
\end{tabular}

**" and "***"Represent that the variable is integrated at $5 \%$ and $1 \%$ respectively.

Source: Researchers' Computation, 2018. P values are in parenthesis

This test was conducted to determine whether each of equations representing each of the two objectives would have equilibrium relationship or not. The test involved subjecting the estimated error term from each of the equations to unit root test as shown in the table 2. For Nigeria and Ghana, the result showed that all the two equations representing the two objectives were cointegrated at either $5 \%$ or $1 \%$ or 
both. All the variables had probability figure less than 0.05 . This implies that the null hypothesis for no cointegration was rejected for all the equations. For South Africa, the results showed that exchange rate equation did not have equilibrium relationship. This implies that the no cointegration hypothesis was not rejected for the equations. Since it has been established that all the variables used in the equations are integrated of order one I\{1\}, the OLS t-values are no longer reliable and cannot be used (Brooks, 2008). Thus the study estimated the short-run dynamic model with error correction.

\subsubsection{Interpretation of Error Correction Estimates Result}

Table 3. Error Correction Estimates the influence of FDI on Exchange Rate (EXR) of Nigeria, Ghana and South Africa

\begin{tabular}{|c|c|c|c|c|c|c|}
\hline \multirow{2}{*}{$\begin{array}{c}\text { Countries } \\
\text { Variable }\end{array}$} & \multicolumn{2}{|c|}{ NIGERIA } & \multicolumn{2}{|c|}{ GHANA } & \multicolumn{2}{|c|}{ SOUTH AFRICA } \\
\hline & Coefficients & P-value. & Coefficients & P-value. & Coefficients & P-value \\
\hline Constant & 0.050379 & 0.0460 & 0.173805 & 0.0168 & 0.032121 & 0.5720 \\
\hline Dlogfdi & -0.010107 & 0.8821 & -0.090835 & 0.3978 & 0.004531 & 0.8882 \\
\hline Dinf & 0.002320 & 0.5496 & 0.014041 & 0.0354 & 0.046629 & 0.0114 \\
\hline Dlogtop & -0.241721 & 0.0051 & -0.264354 & 0.2686 & -1.039770 & 0.1135 \\
\hline Dummy & -0.024108 & 0.4828 & -0.036940 & 0.6599 & 0.039755 & 0.5579 \\
\hline DUMMY*DLNFDI & 0.023726 & 0.8231 & 0.166859 & 0.4057 & -0.024298 & 0.5699 \\
\hline Error(-1) & -0.882684 & 0.0041 & -0.347631 & 0.1104 & NA & NA \\
\hline \multirow{4}{*}{\multicolumn{3}{|c|}{$\begin{array}{l}R^{2}=0.752005 . \text { Adjusted } R^{2}=0.586675 \\
\text { F-Stat= 4.548503; Prob(F-stat.) }=0.021440\end{array}$}} & \multirow{2}{*}{\multicolumn{2}{|c|}{$\begin{array}{l}R^{2}=0.750052 \\
\text { Adjusted } R^{2}=0.58342\end{array}$}} & \multicolumn{2}{|l|}{$\mathrm{R}^{2}=0.671968$} \\
\hline & & & & & Adjusted $R^{2}=0$ & 328 \\
\hline & & & \multicolumn{2}{|l|}{ F-Stat $=4.501248$} & \multicolumn{2}{|c|}{ F-Stat=4.096966; } \\
\hline & & & \multicolumn{2}{|c|}{$\operatorname{Prob}($ F-stat $)=0.023$} & \multicolumn{2}{|c|}{ Prob(F-stat.) $=0.02299$} \\
\hline
\end{tabular}

Source: Researchers' Computation, 2018.

$P$ values are in parenthesis

From table 3, the coefficient of FDI has a negative sign and this implies that increase in FDI reduces exchange rate. The coefficients were negative for Nigeria and Ghana (-0.010107 and -0.090835 respectively). This is in line with economic theory because an increased inflow of FDI is equivalent to an increase in the demand for a country's currency and this makes the exchange rate to fall (a fall in exchange rate means appreciation of currency with respect to other currencies). However, for South Africa, the coefficient of FDI is positive, hence suggesting a contrary view to the theory. The coefficient of FDI appeared not to be significant for all the countries with $p$-value $>0.05$ which signifies that FDI does not significantly impact on the exchange rate in all the countries.

The coefficient of inflation appeared to be positive for all the countries, but significant for Ghana and South Africa and this suggested that inflation depreciated their currencies.

The degree of openness has negative sign in all the countries suggesting that for each country, openness of the economy leads to currency appreciation (coefficients are $-0.241721,-0264354$ and 1.03977 for Nigeria, Ghana and South Africa respectively). It is noted that the higher the degree of openness, the more the FDI that enters into a particular country and also the more the pressure on the country's currency. This invariably will make the currency to appreciate. It appears that degree of openness does not exert any significant impact on the exchange rate of Ghana and South Africa while in Nigeria, openness significantly impacts on exchange rate at 1 percent level of significance.

The coefficient of interactive dummy (dummy multiplied by FDI) is not significant in any of the countries ( $p$-values of $0.8231,0.4057$ and $0.5699>0.05$ ). This means that for all the countries, the impact of FDI on exchange remained the same in both the pre- and post-IFRS.

The adjustment coefficient shows that on the average, about 88 and 35 per cent of the disequilibrium between the dependent and independent variables are corrected at the next period in Nigeria and Ghana respectively. For South Africa, the result in table 4.2.10 did not establish a cointegrating relationship. Thus, there was no adjustment to equilibrium.

The adjusted $R^{2}$ value for Nigeria, Ghana and South Africa were $0.5866,0.5834$ and 0.4533 (that is $58.7,58.3$ and 45.3 percent) changes in the exchange rate of those countries could be attributed to the 
explanatory variables. The remaining balance in each country's percentage relates to other explanatory variables not captured in the model.

The p-value of F-statistic $(0.0214,0.023$ and 0.023 for Nigeria, Ghana and South Africa) indicated significant influence ( $p$-value $<0.05$ ) of joint effect of all the explanatory variables on exchange rate.

For Nigeria, Ghana and South Africa, the $p$-values for the coefficients of multiplicative dummy which were $0.8231,0.4057$ and 0.5699 were significantly above 0.05 at 5 percent level of significance. This implies that the study did not reject the null hypothesis that the influence of foreign direct investment on exchange rate did not significantly differ between the pre and post-IFRS adoption periods in Nigeria, Ghana and South Africa.

Table 4. Error Correction Estimates of the influence of FDI on Domestic Investment (DINV) of Nigeria, Ghana and South Africa

\begin{tabular}{|l|r|r|r|r|r|r|}
\hline \multicolumn{1}{|c|}{ Countries } & \multicolumn{2}{|c|}{ NIGERIA } & \multicolumn{2}{c|}{ GHANA } & \multicolumn{2}{c|}{ SOUTH AFRICA } \\
\hline \multicolumn{1}{|c|}{ Variable } & Coefficients & \multicolumn{1}{c|}{ P-value } & \multicolumn{1}{c|}{ Coefficients } & \multicolumn{1}{c|}{ P-value } & \multicolumn{1}{c|}{ Coefficients } & P-value \\
\hline Constant & 0.223344 & 0.4148 & 0.120872 & 0.1564 & 0.051998 & 0.0557 \\
\hline Dlogfdi & 0.017546 & 0.9818 & 0.139666 & 0.3021 & 0.007218 & 0.6200 \\
\hline Dinf & -0.083376 & 0.0873 & 0.139666 & 0.3021 & 0.004868 & 0.5211 \\
\hline Dlogtop & -1.291633 & 0.1552 & 0.441049 & 0.1090 & 0.521498 & 0.0656 \\
\hline Dummy & -0.294568 & 0.4689 & -0.004333 & 0.9691 & -0.012890 & 0.6545 \\
\hline Dummy*dlnfdi & 0.279231 & 0.8197 & -0.312383 & 0.2551 & 0.016413 & 0.5211 \\
\hline Error(-1) & -0.554175 & 0.0180 & -0.637298 & 0.0348 & -0.236278 & 0.1541 \\
\hline$R^{2}=0.936935$ \\
F-Stat=22.28498
\end{tabular}

Source: Researchers' Computation, 2018.

$P$ values are in parenthesis

The results from table 4 showed that the influence of foreign direct investment (FDI) on domestic investment (DINV) were positive for all the countries but none is statistically significant ( $p$-value of $0.9818>0.05,0.3021>0.05$ and $0.6200>0.05$ for Nigeria, Ghana and South Africa respectively). Though, FDI does exert significant influence on the growth in Nigeria, Ghana and South Africa, the coefficient of DINV appeared highest in Ghana (0.13967) relative to Nigeria and South Africa which were 0.107546 and 0.007218. The coefficient of inflation which is negative $(-0.083376)$ for only Nigeria, though not significant, suggests that inflation is detrimental to the growth in Nigeria. However, for South Africa and Ghana, inflation assumed positive values ( 0.133967 and 0.004868 respectively) implying that it enhances investment. This is not in harmony with the economic theory.

The coefficient of the degree of openness (TOP) appeared negative for Nigeria (-1.292) only. The implication of this is that openness of the economy does not encourage economic growth in Nigeria while it enhances growth in Ghana and South Africa ( 0.4415 and 0.5215 respectively). This scenario is possible and depends on the volume and nature of export relative to import. If the import is higher than export and is biased towards consumption goods, then openness will possibly hurt growth as the case in Nigeria and Ghana but if export is greater than import or import tends more to capital goods or both, the scenario in South Africa becomes applicable.

The coefficient of interactive dummy (dummy multiplied by FDI) is not significant in any of the countries ( $p$-values of $0.8197,0.2551$ and $0.5211<0.05$ ). This means that for all the countries, the influence of FDI on investment remained the same in both the pre- and post-IFRS adoption periods.

The coefficient of the first lag of the error term which is the adjustment coefficient indicates the rate of convergence to the equilibrium when disturbed. For instance, the coefficients for Nigeria, Ghana and South Africa are $-0.5542,-0.6373$ and -0.2363 respectively. This implies that about 55 per cent, 64 per cent and 23 per cent discrepancies between the long-run and short-run are being corrected in Nigeria, Ghana and South Africa in subsequent periods. 
$\mathrm{R}^{2}$ which indicates the effect of the explanatory and extraneous variables on the DI of Nigeria, Ghana and South Africa were $0.9369,0.7508$ and 0.7326 respectively. The adjusted $R^{2}$ value for Nigeria was 0.8949 suggesting that 89.5 percent changes in $\mathrm{DI}$ could be attributed to the explanatory variables while the variables not in the model account for about 10.5 percent. Similarly, for Ghana and South Africa, the adjusted $R^{2}$ values were 0.5202 and 0.5543 respectively suggesting that changes in the 52 and 55.4 per cents in $\mathrm{DI}$ are accounted for by the explanatory variables.

F-statistics for the three countries were statistically significant as all the $p$-values were found to be < 0.05 (0.0211, 0.02 and 0.022 for Nigeria, Ghana and South Africa respectively).

The p-values for the coefficients of multiplicative dummy for Nigeria, Ghana and South Africa which were $0.2792,0.2551$ and 0.5211 were above 0.05 at 5 percent level of significance. This implies that the study did not reject the null hypothesis that the influence of foreign direct investment did not significantly differ between the pre- and post-IFRS adoption periods in Nigeria, Ghana and South Africa.

\subsection{Discussion of Findings}

Objective 1: To determine the influence of FDI on exchange rate in pre- and post-IFRS adoption periods in Nigeria, Ghana and South Africa. The result of the analysis showed that FDI had no significant influence on the exchange rate of Nigeria and Ghana. In specific terms, it showed negative but insignificant influence on the exchange rate of the two countries since the p-values were 0.8821 and 0.3978 , and greater than 0.05 at 5 percent level of significance for Nigeria and Ghana respectively. The coefficients of FDI were negative (- 010107 and - 0.090835) for Nigeria and Ghana respectively. However, for South the coefficient of FDI was positive $(0.004531$ with p-value of 0.8882$)$, hence suggesting something contrary to the normal economic theory. However, in all the countries of the study, the coefficients were statistically insignificant as their $p$-values were $>0.05$.

The effect of foreign direct investment on exchange rate did not significantly differ between the preand post-IFRS adoption in Nigeria, Ghana and South Africa. The p-values for the coefficients of multiplicative dummy were $0.8231,0.4057$ and 0.5699 respectively and were significantly above 0.05 at 5 percent level of significance.

This negative coefficient for Nigeria and Ghana were in agreement with the apriori expectation that FDI should have negative influence. As FDI increases, the exchange rate decreases. A reduction in exchange rate implies currency appreciation. In a similar study in USA, Froot and Stein (1999) found a negative relationship between FDI and exchange rate. This can be explained in two approaches: Firstly, increase in supply of foreign funds means more demand for local currency as those funds would be converted to local currency before utilization for daily operations. FDI are usually associated with movement of major or huge capital which is linked to appreciation of currency of the recipient nation (Lipsey and Chrystal, 2011). Following demand and supply theory, there may be appreciation of currencies (Lily et al, 2014). Secondly, it could come in the form of increased goods for export. For these goods to be bought by foreigners there would be inflow of foreign currencies and appreciation of the local currency through demand and supply mechanisms.

Objective 2: To evaluate the influence of FDI on domestic investment (gross fixed capital formation) in pre- and post-IFRS adoption periods in Nigeria, Ghana and South Africa.

The result showed that the influence of foreign direct investment (FDI) on domestic investment was positive but statistically insignificant for all the countries ( $p$-value of $0.9818>0.05,0.3021>0.05$ and $0.6200>0.05$ for Nigeria, Ghana and South Africa respectively). However, there is no significant difference on the influence of FDI on DI of Nigeria, Ghana and South Africa between pre- and post-IFRS adoption. The positive influence of FDI on DI investment was in accordance with expectation from higher technology, huge capital and benefit from the economies of the scale. Similar discoveries of positive relationship in the short-run and evidence of crowding in or crowing out effect of FDI on DI investment were made by Kabir (2012) in Nigeria and Prasnna (2010) in India. Also, Razi (2004) and Mahmood and Chadhary (2012) had the same result. This could be attributable to the level of technological development in a nation like South Africa. The possibility of product upgrading by 'learn by observing' (Harding and Javorick, 2011) could be higher in South Africa with reflections on the level linkages, increased product quality and output as well as resultant firm prosperity. 
The insignificant difference in the influence of FDI on DI in pre- and post-IFRS adoption era implies that IFRS adoption was not able to attract more FDI. Thus, other factors like institutional developments, security, anti-corruption policies, accountability issues, friendly business environment as well as improvement in basic infrastructure come to play. Similar views were shared by Jayeoba et al. (2016) and Efobi et al. (2014). However, Cristina (2014) found a negative relationship between FDI and DI.

\section{Conclusions and recommendations}

From the findings which showed no significant difference in the exchange rate and DI in the pre- and post- IFRS adoption periods, the study concludes that IFRS adoption by countries is not accompanied by significant increase in FDI inflow. It posits that other factors may be required in association with IFRS adoption to attract FDI. In other words, IFRS adoption alone is not sufficient to attract FDI.

\section{Recommendations}

1. FDI had negative but insignificant influence on exchange rates of Nigeria and Ghana. The Governments of Nigeria and Ghana should therefore, give priority to FDI-led companies. They should make business and diplomatic moves, signing and implementing bilateral, multi-lateral and regional treaties. These policies will help in bringing in the much needed foreign currency by way of FDI which will help in reducing these countries' exchange rate.

2. The positive but insignificant influence of FDI on DI of Nigeria, Ghana and South Africa require that government of these countries should direct effort to ensure FDI inflows in areas where they do not have existing industries to avoid crowding out effect of FDI. This could be in areas like value chain agroallied industries. This area is labour- intensive and as such would create more jobs and greater potentials for linkages and spill-over effect into DI than extractive industries. South Africa should pursue policies to attract FDI more into manufacturing to sustain and improve the effect of FDI on DI than in the area of extractive industry which is capital intensive with little spill-over effect.

\section{Implications of the Findings}

The negative but insignificant influence of FDI on exchange rates of Nigeria and Ghana means that FDI reduces exchange rate in Nigeria and Ghana. That is, as FDI increases, exchange rate decreases. A reduction in exchange rate implies currency appreciation, which implies that the Naira and Cedi appreciated over the dollar. The insignificant nature of it connotes that the contribution of FDI to exchange rate reduction was minimal. However, South Africa had positive sign which means that as FDI increases, Rand decreases. FDI was also found to have had positive but insignificant influence on DI of Nigeria, Ghana and South Africa. This suggests low absorption, that is, poor linkages, technological transfer and spill- over effect. These could be attributable to poor human capital and infrastructure. The poor effect of FDI on DI could be seen in the very low coefficient in the countries of study $(0.017546,0.139666$ and 0.007218$)$ for Nigeria, Ghana and South Africa respectively. The insignificant difference in the influence of FDI on the variables of the study in the pre- and post- IFRS adoption periods connotes that nations adopting IFRS should not do so with the hope of attracting more FDI. This is against the popular belief that IFRS adoption is accompanied by more FDI.

\section{References}

1. Abbas, Q., Akbar, S. Nasir, A. S. Ullah, H. A. \& Naseem, M. A. (2011). Impact of foreign direct investment on gross domestic product. Global Journal of Management and Business Research, 11 (8).

2. Abu, M., \& Achegbulu, J. O. (2011). An investigation of the impact of foreign direct investment on economic growth in Nigeria. International Business and Management, 3(1), 232-238.

3. Adetula, D. T., Nwobu, O. and Owolabi, F. (2014). International financial reporting standards and foreign direct investment in Nigeria. International Journal of Commerce, Business and Management (IJCBM), 3(3), 446-449.

4. Agosin, M. R. \& Mayer, R. (2000). Foreign investment in developing countries, does it crowd in domestic investment? Unctad.org/en/docs/dp_146-en.pdf. 
5. Akpomi, M. E \& Nnadi, M. A. (2017). The impact of international financial reporting standard on foreign direct investment: Evidence from Africa and implication for managers of education. Journal of Accounting and Financial Management, 5(2), 51-65.

6. Alexander, D. Britton, A. \& Jorissen, A. (2009). International financial reporting and analysis, $\left(4^{\text {th }}\right.$ ed.). United Kingdom: Cengage Learning, EMEA.

7. Alfaro, L., Arendam, C. Seberm, K. O. \& Selin, S. (2006) How does foreign direct investment promote economic growth, exploring the effect of financial market on linkages. NBER

8. Amighini, A. A., McMillan, M. \& Sanfilippo, M. (2015). Foreign direct investment as a catalyst for domestic investment in developing economies: New evidence from industry-level data.graduateinstitute.ch/files/lives/sites/iheid/files/.../Amighini\%20et\%20al_master.pdf.

9. Arndt, C., Buch, C. M. \& Schniter, M. (2007) Foreign direct investment and domestic investment: An industrial-level view. Governance and the Efficiency of Economic System, Discussion Paper No. 22.

10. Aveh, F.K., Krah, R. Y. \& Dadzie, P. (2013). Acccounting for foreign direct investment on Ghanaian economy, International Business and Management, 6(2), 121-130.

11. Begg, D., Fischer, S. \& Dornbusch, R. (2008). Economics. ( $9^{\text {th }}$ ed.). New York (USA): Mc Graw-Hill Higher Education.

12. Brooks, C (2008), Introductory economrtrics for finance $\left(2^{\text {nd }}\right.$ ed.). New York: Cambridge University Press.

13. Colling, S. (2012). IFRS for dummies. West Sussek, England: John Wiley and Sons LTD.

14. Cristina, J. (2014). Does foreign direct investment crowd out domestic investment in transition countries. www.touteconomie.org/afse2014/index.php/meeting2014/lyon/paper/view/86/44

15. Denisia, V. (2010). Foreign direct investment theories: An overview of the main FDI theories. European Journal of Interdisciplinary studies, 3, 53-59.

16. Dunnig, J. H. (1998a). Location and multinational enterprise: A neglected factor? Journal of international Business Studies, 1(29)

17. Dunning, J. H. (1988). The elective paradigm of international production: A restatement and some possible extension. Journal of International Business Studies, 19(1),1-31.

18. Efobi, U. Nnadi, M. Odebiyi, J. \& Beecroft, I. (2014). Retrieved from http://ssrn.com/ abstract $=2460967$

19. Epstein, B. J. \& Jermakowic (2009). IFRS interpretations and application of international financial reporting standard. New Jersey: John Wiley and Sons Inc.

20. Ezejelue, A. C. (2001). A Primer on International Accounting. Port-Harcourt: Educational Books and Investments Limited

21. Froot, K.A. \& Stein, J. (1991). Exchange rate and foreign direct investment: An imperfect capital markets approach. www.people.libs.edu/kfroot/oldwesite/cvpaperlinks/echangerate

22. Ghana Investment Promotion Centre Act 2013 (865). www.gipcghana.com/about.html.

23. Goldberg, L. S. (2006). Exchange rate and foreign direct investment, Https://www. newforkfed.org/medialibrary/media/research/economist/goldberg/ERandFDlarticlehlodberg.pdf

24. Gordon, L. A., Loeb, M. P. \& Zhu, W. (2012). The impact of IFRS adoption on foreign direct investment. Journal of Accounting and Public Policy, 31(4), 374-398

25. Graham, E. M. (1995). Foreign direct investment in the world economy. IMF Working Paper, 95/59, International Monetary Fund

26. Gujarati, D, N., Porter, D. C. \& Gunasekar, S. (2009). Basic Econometrics (5 $5^{\text {th }}$ ed.). New Delhi. Tata McGraw-Hill Education Private Limited,

27. Gujarati, D. N (2004). Basic Econometrics, ( $4^{\text {th }}$ ed.). The McGraw-Hill Companies

28. Harding, T. \& Jarvorcik, B. S. (2011). Can foreign direct investment help developing countries upgrade export quality? Voxeu.org/article/can-fdi-help-developing-countries-upgrade-export-quality

29. Henock, L. \& Oktay, U. (2012). The effect of IFRS on foreign direct investments: Evidence form cross-border acquisitions. www.fox.temple.edu/cms/wp-content/upload/2012/08/ifrs_4_2012.pdf 1-41.

30. Jayeoba, O. O., Ajibade, A. T., Olayinka, I. M., Ogundajo, G. O. \& Kwarbai, J. D. ((2016). Accounting standards and foreign direct investment inflows in selected African countries (1980-2015). International Journal of Advanced Academic Research/ social\& Management Sciences, 2(10), 17-25. 
31. Jinadu,O., Ojeka, S. A. \& Ogundana, O. M. (2016). IFRS adoption and foreign direct investment: Evidence from Nigerian quoted firms. Mediterranean Journal of Social Sciences, 7(2) 99-105

32. Kabir, H. D. (2012). Foreign direct investment and the Nigerian economy. American Journal of Economics, 2(3), 33-40.

33. Kanu, S. I. (2015). Foreign capital inflows and economic growth in Sub-Saharan Africa: A study of selected countries. Research Journal of Finance and Accounting, 6(1), 1-24.

34. Lily, J., Kogid, M. Mulok, D., Sang, L. T. \& Asid (2014). Exchange rate movement and foreign direct investment in Asean economies. Economics Research International, 2014(2014)

35. Lipsey, R. G. \& Chrystal, K. A. (2011). Economics (12 ${ }^{\text {th }}$ ed.). New York: Oxford University Press inc.

36. Mahmood. H \& Chaudhary, A. R. (2012). Foreign direct investment-domestic investment nexus in Pakistan. Middle-East Journal of Scientific Research, 11(11), 1500-1507.

37. Meigs, R. F., Williams, J. R. \& Bettner, S. S. (1999). Accounting basis for business decisions, $\left(11^{\text {th }}\right.$ ed.). USA: Irwin Mc Graw-hill

38. Ndikumana, L. \& Verick, S. (2007). The linkages between foreign direct investment and domestic investment: Unravelling the developmental impact of foreign investment. Scholars work at University of Massachusetts, Economics department working paper series, 25. Http://scholarwork.umass.edu/ econ_working paper

39. Nigerian Investment Promotion Commission 1995 (16) www.NIPC.gov.ng/NIPCACT.pdf

40. Nwaimo, C. E. (2009). Applied principles of economics (for students and professionals). Owerri: Supreme Publishers

41. Omoniyi, B. B. \& Omobitan, O. A. (2011). The impact of foreign direct investment in economic growth in Nigeria. International Research Journal of Finance and Economics, 73.

42. Organisation for Economic Co-operation and Development (1996). Detailed benchmark definition of foreign direct investment ( $3^{\text {rd }}$ ed. BD3). Paris.

43. Osigwe, A. C. \& Uzonwanne, M. C. (2015). Causal relationship among foreign reserve, exchange rate and foreign direct investment: Evidence from Nigeria. International Journal of Economics and Finance, $5(4), 884-888$.

44. Otto, G. \& Ukpere, W. I. (2014). Foreign direct investment and economic development and growth in Nigeria. Mediterranean Journal of Social Sciences, 5(2), 713-721.

45. Prasanna, N. (2010). Direct and indirect impact of foreign direct investment on domestic investment in India. J Economics, 1(2), 77-83.

46. Premium Times (2016, September 22). Nigerian senate hears how MTN allegedly laundered US\$ 12 billion. www.premiumtimesng.com/news/headlines/211026-Nigerian_senate_hears_...html

47. Pricope, C. F. (2017). The implication of IFRS adoption on FDI in poor countries. Audit Financiar, $\mathrm{xv}, \mathrm{Nr} .2(146), 218-229$

48. Razin, A. (2004). The contribution of foreign direct investment to domestic investment in capacity, and vice versa, NBER Working Paper C10747. www.neber.org/chapter/c10747.pdf.

49. Republic of South Africa, Department of Trade and Industry, http://www.dti.gov.za/ about_dti.jsp.

50. Sherman, $T$ \& de Klerk, M.. (2015). International accounting reporting standards and foreign ownership in South African companies. South African Business Review, 19(1), 72-88.

51. Teshepo, M. (2014). The impact of foreign direct investment on economic growth and employment in South Africa: A time series analysis. Mediterranean Journal of social Science, 5(25), 18-27.

52. Ugwu, J. I. (2017). Effect of foreign direct investment on economic growth of selected Sub Saharan African countries. A Ph.D dissertation submitted to the Department of Accountancy, School of Post Graduate Studies, Nnamdi Azikiwe University, Awka, Nigeria.

53. Ullah, I., Shah, M. \& Khan, F. U. (2014). Domestic investment, foreign direct investment and economic growth nexus: A case of Pakistan. Economics Research International, 2014(2014).

54. UNCTAD, (2016b). World Investment Report, Annex Table, UN reports foreign direct Investment. Unctad.org/en/pages/DIAE/world-investment-report. 